\title{
The Racial Justice for the Windrush Generation in Great Britain
}

\author{
Anthony G. Reddie
}

\begin{abstract}
In this paper, the author, a well known Black British liberation theologian, who is a child of the Windrush Generation, argues that the struggle of the 'Windrush Generation', Black Caribbean post Second World War II migrants to the UK, has been one constant struggle for racial justice. Living in Britain has been undertaken against the backdrop of Mission Christianity that has exuded a distinct anti Blackness in its relationship with Black bodies across four centuries. This particular dynamic of 'Christian Britain' is one that has created a framework that has helped to shape the agency of Black bodies, essentially marking them as 'less than'. This theo-cultural framework has led to a racialised existence for Black British people of the Windrush Generation and their descendants, in which the Christianity that has emerged from the Black Caribbean experience is one that is constantly challenging White British Christianity to express an racist and more inclusive model of liberative praxis. This paper is written against the backdrop of the Brexit furore in Britain and the xenophobia and rise in racist attacks that has underpinned the rise in White British nationalism.
\end{abstract}

Keywords: Windrush Generation; Brexit; British nationalism, Mission Christianity;

This paper is written against the backdrop of Brexit. Its concerns are not concerned with the specifics of whether Britain should remain in or leave the European Union. At the time of writing, Britain is mired in the political paralysis of whether to leave the EU and if so then on what terms, indeed if we choose to leave at all. This paper offers no opinion on the political matter of remaining or leaving, although I voted to 'Remain'. This ambivalence arises from the belief that whether we do so or not, nothing will change the toxic climate that has been unleashed by the Leave Campaign. Whether Britain leaves or not, a majority of the nation has spoken its mind, in terms of aligning with a toxic, xenophobic fuelled subtext of the Leave Campaign that othered visible minorities and created an explicit White centred discourse around the nature of Britishness and notions of belonging. The topicality of Brexit will wane but the sense that Britain has been dragged back into 'dark ages' racist rhetoric from the late 1950s and 60s will remain.

I am part of a wider community. The mass migratory movement of Black people from Africa and the Caribbean in the years following the end of the World War II is termed the 
'Windrush' epoch. This migratory movement commenced with the arrival of 492 Caribbean people at Tilbury docks on the ship The SS Empire Windrush, on the 22 $2^{\text {nd }}$ June 1948.

\section{My subjective background}

The author of this piece is a Black Theologian and Christian educator born in Britain. I was born in Bradford West Yorkshire to Jamaican parents who came to this country from the Caribbean in the late 1950s. As such, I am a second generation Black Caribbean British subject. I was born into and nurtured within the Christian faith from the Wesleyan Methodist tradition. I ply my trade as a Black Liberation Theologian and educator in Birmingham, from where I have lived, for approaching the past thirty years of my life.

I have shared these bare details of my life with you because it is my firm belief that all knowledge, and the writing that emerges from it, is embodied. By this, I mean, there is always a relationship between the experiences that have shaped one's life and the resulting ideas and theories that emerge in any subsequent writing. Namely, that all knowledge and truth is contextual; it emerges from and is shaped by specific and particular times and spaces! Many of the enduring values in my life can be traced back to my formative years growing up in a Black Christian home but living within a predominantly White working class, trade union and Independent Labour Party strong hold of East Bowling. In this context, nonconformism, trade unions and labour party politics went hand-hand-in-hand.

Whilst my formative years were largely pleasant and affirming, what could not be disguised about our existence was the persistent reality of racism that affected the lives of all nonWhite people in the city of Bradford. I would argue that the consistent and persistent challenge that has faced Black people of Christian faith in Britain has been that of trying to get White Christianity to give expression to a non-racist articulation of the gospel. In using the term 'White Christianity' I am talking about people of European extraction and descent, 
who form the majority of the population, who believe in the God revealed in Jesus Christ and seek to give expression to the central tenets of the Christian faith in myriad forms of socialcultural practices.

\section{Racism in Britain and the Black Christian Experience}

The existence of racism in Britain today and in many parts of the so-called developed West, as we speak, is testament to the continuance of an underlying Eurocentric Judeo-Christian framework that has invariably caricatured Africans as 'less than' and 'the other' and often placed White Euro-Americans as the apex of human civilization. The notion that human beings can be categorized into a fixed set of identities, which characterise human potential and capability; often effected in notions of morality and ethics, can be traced back to first four centuries of the 'Common Era' (CE). It was during this epoch that negative connotations pertaining to Black people as the 'other' begin to surface in Christian thinking. ${ }^{1}$

The scourge of racism in Britain is nothing new for Black people. As Beckford has demonstrated, one can chart a genealogy of racism in European intellectual thought that has exerted a disproportionately negative hold on the life experiences of Black people. ${ }^{2}$ Scholars, such as Eze, have shown the extent to which the allegedly enlightened thinking of such 'luminaries' as Hume and Kant was infected with the stain of White supremacist thought. ${ }^{3}$ The construction of the binary of Blackness (as bestial and less than) and Whiteness (as the personification of goodness and the opposite of Blackness) is a product of the modernity. ${ }^{4}$

The chief legacy of transatlantic slavery was the unleashing of the rampageous and ravenous animal that is racism. The construction of racialized notions of fixed identity and restricted perspectives on Black human selfhood were the dangerous offspring of the chattel slavery of the 'Black' Atlantic. ${ }^{5}$ The outworking of an immutable hierarchical manipulation of humanity did not disappear when the Act to abolish the British slave trade was passed in Britain in 
1807. The act brought the making of slaves to an end but racism, the notion of White supremacist norms, most certainly did not end.

\section{Anti-Blackness in Mission Christianity}

The critical construction of Black bodies as the other within the body politic of the nation finds its underscoring in the development of Mission Christianity, out of which emerged the critical dialectic of oppressed Black bodies and White hegemonic power. In using the term 'Mission Christianity' I am speaking of a historical phenomenon in which there is existed (and continues to this day) an interpenetrating relationship between European expansionism, notions of White superiority and the material artefacts of the apparatus of Empire. This form of Christianity became the conduit for the expansion of Eurocentric models of Christianity in which ethnocentric conceptualisation of civilisation gave rise to notions of superiority, manifest destiny and entitlement. ${ }^{6}$

The problem with the historical enactment of Western Missionary Christianity as it is arose from the mandates outlined in the "Great Commission," was that, allied to Eurocentric notions of superiority and White supremacy, it assisted in giving rise to European mercantilist expansion, and the conquest of non-European cultures. African American Womanist theologian Linda Thomas critiques the Matthean tradition of mission, arguing that the locus of power lies with those who are sent as opposed to those who are the recipients of such missionary activities. ${ }^{8}$ The missionary impulse of the "Great Commission" was interpreted as a means of imposing Eurocentric values on the cultures of non-European peoples across the world, arising on the basis of the superiority of White European religio-cultural aesthetics and theological norms.

Western Missionary Christianity formed a collusive relationship with White European hegemony that assisted in providing the theological under-scoring for the transatlantic slave 
trade. When English travellers first began to encounter Black people on a prolonged basisparticularly, through their excursions onto the African continent - it soon became clear that their existing notions of anti-Blackness were buried deep in their theology, which helped to give rise to dangerous notions of African "otherness." 9 The tensions and contradictions between religion, faith, ethnicity and nationality were exploited by means of "specious" forms of Biblical interpretation. One of the main "proof" texts that resolved the issue for justifying the enslavement of Africans within a Christian framework was Genesis 9:18-25 "The Curse of Ham." Noah punishes his son Ham by cursing his own grandson Canaan (the son of Ham), condemning him and all his descencents to slavery. ${ }^{10}$

\section{Black Bodies as Problematic in Mission Christianity}

A central feature of Mission Christianity was its construction of the Black body as other. To understand the extent to which Black bodies have been constricted by racism in Postcolonial, Post Brexit, Britain, we have to remind ourselves that in Mission Christianity, the Black body and therefore the lives attached to those bodies were considered expendable. Anthony Pinn has undertaken detailed work investigating the dialectic of the existential, material realities of Black bodies and the phenomenon that is Christianity. ${ }^{11}$ In Terror and Triumph, Pinn rehearses the contested and troubled relationship between White slave holding Christianity and Black bodies, outlining the levels of demonization and virulent denigration that provided the essential backdrop to transatlantic chattel slavery. ${ }^{12}$ Outlining the apparent ease and the complicity with which Christianity colluded with the epistemological frameworks that underpinned the machinery of slavery, Pinn writes

In short, Scripture required that English Christians begin their thinking on Africans with an understanding that Africans had the same creator. Yet they were at least physically and culturally different, and this difference had to be accounted for. As we shall see, a sense of shared creation did not prohibit a ranking within the created order, one in which Africans were much lower than Europeans. ${ }^{13}$ 
The sense of a deep prevailing anti-Black sentiment replete with notions of Greek antiquity ${ }^{14}$ and practiced within Western (particularly English), Missionary Christianity was given added piquancy in the deliberate attempt to use the developments of early Christian theology as a means of reinforcing the essentially depraved and base status of the Black body. ${ }^{15}$

Kelly Brown Douglas demonstrates how a particular outworking of Pauline, platonized theology (one that downplays the concrete materiality of the body in favor of the abstract and the spirit) was used as a means of demonizing Black bodies. ${ }^{16}$ Kelly Brown

Douglas writes

Accordingly, it is platonized Christianity that gives rise to Christian participation in contemptible acts and attacks against human bodies, like those against Black bodies. Not only does platonized Christianity provide a foundation for easily disregarding certain bodies, but it also allows for the demonization of those persons who have been sexualised. ${ }^{17}$

One can amplify the prevailing sense of an incipient anti-Black strain within the corporate edifice of Western Missionary Christianity when one considers the ways in which Black Christianity itself has imbibed the strictures against the Black body in its own corporate operations of religiosity. Anthony Pinn, drawing on a similar analysis of Platonized, Pauline theology, argues that Black Christianity in the USA and the UK also, has imbibed the prevalent suspicion surrounding the Black body. It has taught many Black Christians to remain at best indifferent to the material needs of the Black body or to seek to transcend its supposed, despised nature; this demonization emerging from the tenets of White Christian slaveholding, thought and practice..$^{18}$

The product of this continued sense of the ongoing demonization of Blackness can be seen in the ways in which Britain has remained ambiguous at best to the material and cultural realities of Blackness. The continued sense of contested notions of self as it pertains to engaging with issues of Blackness remains replete within British Christianity. It can be 
argued that this dialectical struggle has its roots in the misinformation imparted to Black people by their slave masters during the epoch of slavery and in the era of colonialism. ${ }^{19}$

Black British Pastoral theologian, Delroy Hall has written movingly and persuasively, on the Windrush generation in Britain, describing our existence as one of 'Existential Crucifixion'. ${ }^{20}$ Hall argues that Diasporan African peoples have endured the horrors of 'Good Friday' and our existential crucifixions at the hands of White hegemony, through the privations of slavery, colonialism and neo-colonialism, but the exulting freedom of 'Easter Sunday' has yet to materialize. In effect, Diasporan African peoples are still wrestling with an acute sense of being mired in 'Low Saturday' or 'Holy Saturday', stuck in a socio-religious and political form of liminality that speaks to the transformative nature of redemptive suffering that has thus far proved to be anything but redemptive..$^{21}$

The continued marginalization and suffering of Black people has raised an important, if not seemingly insoluble theological problem of trying to correlate the agency of an omnipotent God with the ongoing negation of faithful peoples who have called repeatedly on God to end their existential travails, but to no avail!

It is interesting to note the extent to which those on the political right are now using religion and the construction of Whiteness and Christianity as a means of arguing against the continued presence of Black and Asian people in Britain on the grounds that we are threatening the 'Christian heritage of the nation', i.e. Christianity equals Whiteness. ${ }^{22}$ So a form of subterranean Whiteness becomes emblematic for the socio-cultural and political framing of belonging that constructs semiotic borders within the body politic that is Britain. In effect, the furore caused by the attempted deportation of the Windrush Generation is predicated on a semantic demarcation between Whiteness and Blackness, in which the boundaries between the Whiteness of belonging and the otherness of Blackness of the Windrush Generation is such that even the normal rules of civility around nationality and 
common decency are exposed as illusionary. African American Womanist Ethicist Emilie Townes has written about the cultural construction of evil via the media depictions of Blackness, and how the toxic ephemera of the media exacerbate this hegemonic dynamic of White supremacy. ${ }^{23}$ Townes' penetrating analysis of the cultural production of western life reminds us of the embedded ways in which Blackness is fixed in the popular imagination. ${ }^{24}$ The objectification of Blackness is echoed in the literary and media production that is resonant in the public landscape of the west, particularly, in the US. ${ }^{25}$ One can see this displayed quite markedly in a high profile interview between Piers Morgan and Diane Abbott on 'Good Morning Britain', following the furore over the deportation of the Windrush Generation. Morgan repeatedly asked Diane Abbott to clarify her position and that of the opposition Labour party regarding levels of illegal immigration her party would tolerate in Britain, linking that to the Windrush Generation. The tendentious point Morgan seemed to want to make was linking the Windrush generation to the issue of illegal immigration. The Windrush Generation are NOT illegal immigrants, but British citizens, many of whom came to Britain on British passports. My own parents travelled to Britain from Jamaica in 1957 on British passports because at that point in history, Jamaica was still a crown colony and a part of British Empire and would not achieve her independence until August 1962. And yet, despite the repeated reminders that this issue was one of callous racism at the behest of the British state and not one of illegal immigration, Morgan continued to press Abbott about illegal immigration. ${ }^{26}$ Morgan's insistence on linking the Windrush Generation to illegal immigration simply reminds us that even legal Black British subjects are somehow intrinsically illegal, no matter what the law may state, simply by virtue of our Black skin.

Blackness is othered behind a culturally constructed, media influenced wall, that situates the Windrush Generation as the seemingly disposable entities on the sharp end of the vituperative rhetoric of entitled Whiteness that provides the underpinning of Britishness. 


\section{The Problematics of Black People in Britain}

The recent furore in the UK around the potential deportation of Caribbean migrants has galvanized the body politic of the nation in ways that have proved surprising and challenging for many. The sense of outrage felt by many ordinary British people has surprised many in the news media. The construction of the binary of the privilege of Whiteness juxtaposed with those who are othered is one that is replete within the English psyche. The recent actions of the government in trying to deport Black Caribbean people whose citizenship was held in question due to governmental conspiracy or incompetency was but the sharp end of a continuum of the racialization of Black bodies that has been centuries in the making. ${ }^{27}$ The virulently racist treatment meted out to Black people of the Windrush Generation is all the more unpalatable in that it exacerbates the already pernicious nature of being 'othered' in a nation that often wants to exemplify homogeneity and sameness. The statistics that surround Black and Asian lives in Britain largely make for grim reading. Living here is never easy or without its struggles. The vast bulk of our numbers, for example, remain at the bottom of the socio-economic ladder. ${ }^{28}$

The irony of our residency in this country is that it has never been a benign or non-contested existence. The socio-politicised nature of Black bodies residing in Britain is neither a new nor a surprising phenomenon. ${ }^{29}$ Once you start from the premise that some people really do belong and deserve to do so and others do not, then it becomes almost axiomatic that particular practices will develop and legislation be passed which in turn lead to the penalising and detrimental treatment meted out to Black people.

The racist frameworks of 'them' and 'us' create the template in which stereotyping, discrimination and marginalisation become commonplace, leading to the blunt instrument of loyal and largely supine Black people being threatened with deportation when they have been British citizens of many years standing. The punishment of Black people fits into a long 
established pattern, deep within White religious discourse, that Black people and other minority ethnic peoples deserve to be ill-treated, because deep down, they are not of the same substance as 'normal White people'. ${ }^{30}$ That is, notions of ontological difference between Whiteness and Blackness continue to underpin how we assess the qualitative importance of the latter in the body politic of the nation.

Thinking back to the death of the Black teenager, Stephen Lawrence, now more than twentyfive years ago, is a painful reminder of the disposability of Black bodies. Stephen Lawrence was a Black teenager of blameless character who was brutally murdered on the April $18^{\text {th }}$ 1993, in the South-East London borough of Eltham.

In this notorious case, one witnesses the existence of what I have termed 'contractual compassion' within the body politic of the nation. In using his phrase, I am arguing that the strictures of a repressed and dichotomous form of dualism ${ }^{31}$ (one that divides the world and people into those who are righteous and 'of God' and those who are of 'the World' and are not) is one that makes crucial determinations between those who are deserving, and those who are not. We see this form of contractual dualism in how we assess issues of social class and economics. We have the language of the 'deserving and undeserving poor', some poor people deserve support and encouragement whilst other people deserve to be punished for their lazy and feckless behaviour. Curiously and perhaps, unsurprisingly, we have no equivalent language for the undeserving rich!

In the case of Black bodies, because we are seen as the 'other' and are inherently transgressive and accompanied with a problematic ontology, sympathy, and therefore justice, as a response to racialised violence can only become operative when the recipient of such violence is seen to be blameless. That is to say, a form of respectability politics are at play in terms of how Black lives are assessed for their worth and value. It is no coincidence that in the case of Stephen Lawrence, when the police first arrived on the scene of his murder, their 
first instinct was to assume that he was guilty of something, even though he lay on the ground fatally injured. ${ }^{32}$

The next line of inquiry was predicated on the notion that he was a member of a gang and that this incident, which subsequently led to his death, was a product of gang-related violence. It was only when all the traditionally racialised lines of inquiry had been exhausted and no apportion of blame could be levelled at this Black youth of 'dubious character and virtue' that the British press then threw their weight and influence behind the campaign to find his killers. The support of the British press emerged once all the, hitherto, non-contested frameworks that posit the notion of Black people as the 'other' had been exhausted and not before. In terms of the controversy over the deportation of members of the Windrush Generation and their descendants, the amelioration of this state sanctioned exercise in bad faith is still predicated on the benign and passive suffering of predominantly elderly, non controversial figures. In other words, the public opprobrium at the punitive treatment of Windrush Generation was operative because these were inoffensive and largely supine, older Black people. Middle England and the machinations of the media would not have been so supportive if the people being deported were inner city Black Muslim youths of allegedly dubious character.

The toxicity of the hostile climate on immigration was such that it has helped to create a contemporary epoch in which White entitlement has reasserted itself, blaming migrants and minorities for the social ills that plague the nation. In the context of this paper on Black Lives mattering, I have noted the distinct diffidence with which the church responded to the phenomenon of Brexit, the success of which helped to fuel the state sanctioned hubris of deporting British citizens via a toxic environment for which many White people voted. I have yet to find any church leader who has identified, unambiguously, with the cause of marginalised Black and minority ethnic people who have been othered in the Brexit 
phenomenon, which gave rise to the policies of the former Home Secretary, Amber Rudd. I have personally sat in meetings and watched and listened to predominantly White leaders pander to the toxic rhetoric that others? Black bodies and minority ethnic migrants in order to placate the wounded psyche of White privilege and entitlement.

Ironically, many show more care for dissatisfied and disillusioned White people who largely do not attend their churches than to Black migrants who do so, in disproportionately large numbers - often maintaining inner cities after they had been vacated by 'White flight' in the 1980s and early 90s. In making this comment, I am not suggesting that White majority do not have Black leadership within their churches or that Black people are not evidence in leadership positions. My critique of the apparent silence of White leaders refers to the lack of any substantive challenge to the rampant xenophobia and racism of the Leave Campaign and its vilification and othering of visible migrants and the anti-immigration discourse that underpinned Brexit. It can be argued that alongside the National Health Service, London Transport and British Christianity, especially White majority churches have been the greatest beneficiaries of immigration from the countries of the former British empire. ${ }^{33}$ The failure of White leaders to challenge the tone and even the legitimacy of the anti-immigration rhetoric of the Leave Campaign was a failure to appreciate the significance of the Black contribution to churches in the inner city conurbations, often existing as Black enclaves long after White middle class people had left and without any significant presence of White working class people many whom voted in significant numbers for Brexit.

It is interesting to note the ways in which church leaders in Britain whilst challenging the more jingoistic elements of the Leave Campaign, nevertheless, refused to critique the concerns over immigration as being part of an orchestrated attempt at obfuscation. So, blame can heaped upon migrants for the strain on resources that are disadvantaging the entitlement of poor White people whilst ignoring the neo-liberal social and economic policies that have 
marginalised these communities for the past two hundred years. The latter occurred whilst British imperialism was being orchestrated across the world, when migrants were not much evidence in the country. ${ }^{34}$ As I reiterate, Black lives do not matter in the body politic of Great Britain!

\section{The Challenge to White Christianity in Britain}

The presence of the Windrush Generation has challenged the scourge of racism as it has sought to effect unity within the Body of Christ. At the heart of this challenge, whether utilising a Colour Blind approach, or one based on expressing a contextualised, religiouscultural articulation of Black Christian experience, or the approach located in the practice of Black Theology, has been the challenge to White Christianity to live out the gospel imperative to love one another as humanity has been loved by Christ. The challenges of John 13: 31-35 are real and have bedevilled White Christianity in Britain for centuries. This new commandment from Jesus sits at the heart of the Christian message and has implications for those inside and outside the community of faith.

Inside the faith, the followers of Christ are asked to love another for 'by this, everyone will know that you are my disciples' (v.35). The way in which the followers love one another will be a sign of their commitment to and belonging within the common life of faith in Christ Jesus.

Sadly, looking back on the events of 2007, a year in which we remembered the bicentenary of the abolition of the slave trade, the ancestors of Diasporan Black peoples; the ones who were themselves enslaved Africans, many of these people would no doubt have reflected ruefully on this text. For many Black Christians, our becoming members of the Body Christ did not change how significant numbers of White Christians saw us or treated us.

Even when Black people became Christians there was little evidence of this love ethic displayed in the actions of many White Christians. ${ }^{35}$ When many Black people travelled to 
the UK in the post war Second World War migration of the 1950s and 1960s where was the outpouring of love for one another upon their arrival in post war Britain?

It is no wonder, then, that many Black Christians have questioned the alleged nature of socalled White, British Christianity. ${ }^{36}$ Looking from the outside in, some older Black Christians of the 'Windrush' generation have wondered whether many 'good White English Christians' have ever read and understood this passage at all ${ }^{37}$

White English Christianity must be committed to a ruthless and fiercely argued critique of its Whiteness, in a manner that accords with the existential struggling for truth that Black people have been obliged and sometimes forced to undertake since the creation of modernity ${ }^{38}$ In critiquing Whiteness, I am talking about a thorough deconstruction of toxic relationship between Christianity, Empire and notions of White-British superiority. ${ }^{39}$

The quest for equity, liberation and justice is one that requires the committed determined action of all peoples, irrespective of faith commitment (plus those who profess to hold no such notions). But it also requires truth telling and a retreat from all forms of obfuscation that blind us to the structural and systematic forms of racism that continue to oppress Black people and other minority ethnic people in Britain. Whether we wish to acknowledge it or not, privilege and notions of who is important, has a colour. Similarly, systemic power and notions of belonging and what is deemed acceptable also has a colour. The failure to name and unmask these forms of unearned privilege has been, for me, the most telling indictment of White Christianity in Britain. The days of Black people having to struggle with the pernicious patterns of socio-cultural and religious "double jeopardy" (we have to solve our own problems and those of White people also, who for most part, have to failed to address their own Whiteness) should be at an end. 
The task of unmasking the privileged construct of Whiteness is not a task for Black theologians alone. Conversely, the task of effecting the systemic and structural changes that better reflect the Kingdom of God within the urban context is a task for us all.

The future can be remade! Let us have faith in the light of the Spirit of God to banish the darkness of racism and oppressive, bad practice that so often litters our past and our present. The light awaits! Let us bask in the light!

\section{References}


${ }^{1}$ See Robert E. Hood Begrimed and Black: Christian Traditions on Blacks and Blackness (Minneapolis: Fortress press, 1994), pp.23-43

2 Robert Beckford, Dread and Pentecostal (London: SPCK, 2000) pp.95-130.

3 See Emmanuel C. Eze, 'Race' and the Enlightenment Oxford: Blackwell, 1997).

4 See James W. Perkinson, White Theology (New York: Palgrave, 2004), 154-84.

5 Dwight N. Hopkins, Being Human: 'Race' Culture and Religion (Minneapolis: Fortress Press,

2005), pp.144-60.

${ }^{6}$ See T.J. Gorringe Furthering Humanity: A Theology of Culture (Basingstoke: Ashgate, 2004). See also John M. Hull Towards the Prophetic Church: A Study of Christian Mission (London: SCM press, 2014).

${ }^{7}$ The nomenclature often identified as "The Great Commission" is seen as the primary proof text for legitimizing the missionary intent of the Christian faith as it pertains to non-European cultures and contexts. For the purposes of this essay, the relevant words of the "Great Commission" are to be found in Matthew 28, vv. 20, which states "and teach them to do everything I have told you." The teaching ministry of the church has arisen from the mandate to "make new disciples" of Jesus Christ. The establishment of new churches in the Mediterranean during the second half of the first century of the "Common Era" was often predicated on the replication of Christian ideas, combined with human socialization in the power of the Holy Spirit, in which, new recruits were placed in proximity with more established believers within a powerful framework of an emerging Christian narrative. See Stanley Hauerwas, "The Gesture of a Truthful Story," in Jeff Astley, Leslie J. Francis, and Colin Crowder, eds., Theological Perspectives on Christian Formation: A Reader on

Theology and Christian Education (Grand Rapids, MI: Wm. B Eerdmans, 1996), pp.97-105. See also Craig Dykstra, "No Longer Strangers: The Church and its Educational Ministry," in Jeff Astley, Leslie J. Francis, and Colin Crowder, eds., Theological Perspectives on Christian Formation, pp.106-18.

${ }^{8}$ See Linda E. Thomas, “Anthropology, Mission and the African Woman: A Womanist Approach,” Black Theology: An International Journal 5, no.1 (2007): 11-19.

${ }^{9}$ See Ron Ramdin, Reimaging Britain (London: Pluto Press, 1999), 5-10.

${ }^{10}$ See Stephen R. Haynes, Noah's Curse: The Biblical Justification of Slavery (Oxford \& New York: Oxford University Press, 2002). See also Sylvester A. Johnson, The Myth of Ham in Nineteenth-Century American Christianity (New York: Palgrave Macmillan, 2004).

${ }^{11}$ See Anthony B. Pinn, Terror and Triumph: The Nature of Black Religion (Minneapolis, MN: Fortress Press, 2003). See also Anthony B. Pinn and Dwight N. Hopkins, eds., Loving The Body: Black Religious Studies and the Erotic (New York: Palgrave Macmillan, 2004) and Anthony B. Pin, ed., Black Religion and Aesthetics: Religious Thought and Life in Africa and The African Diaspora (New York: Palgrave Macmillan, 2009).

${ }^{12}$ Pinn, Terror and Triumph, p.1-80.

${ }^{13}$ Pinn, Terror and Triumph, p.6.

${ }^{14}$ This phenomenon and theme has been explored by Robert E. Hood, Begrimed and Black: Christian Traditions on Blacks and Blackness (Minneapolis, MN: Fortress Press, 1994).

${ }^{15}$ This idea is taken from Kelly Brown Douglas' excellent study on Black bodies and how they have been policed and controlled within the religious framework of Christianity. See Kelly Brown Douglas, What's Faith Got To Do With it? Black Bodies/Christian Souls (Maryknoll, NY: Orbis, 2005).

${ }^{16}$ Kelly Brown Douglas What's Faith Got To Do With it?, pp.3-38.

${ }^{17}$ Kelly Brown Douglas What's Faith Got To Do With it?, p.37

${ }^{18}$ Anthony Pinn "Introduction," in Loving The Body, pp.1-8.

${ }^{19}$ See the work of the great African American historian Carter G. Woodson for work that reflects on the notion of identity struggle of Black people that often arises from various forms of mis-education organized and perpetrated by White power. See Carter G. Wood- son, The Mis-Education of the Negro (Trenton, NJ: Africa World Press, [1933] 1990).

${ }^{20}$ See Delroy Hall 'The Middle Passage as Existential Crucifixion'. Black Theology: An International Journal, Vol.7, No.1, 2009, pp.45-63.

${ }^{21}$ Delroy Hall, 'The Middle Passage as Existential Crucifixion', pp.46-54

${ }^{22}$ See The Methodist Recorder - Front page story, $16^{\text {th }}$ March, 2006

${ }^{23}$ See Emilie M. Townes Womanist Ethics and the Cultural Production of Evil (New York: Palgrave Macmillan, 2006)

${ }^{24}$ Emilie M. Townes Womanist Ethics, pp.11-55

${ }^{25}$ Emilie M. Townes Womanist Ethics, pp.29-55

${ }^{26}$ For a precis of the interview see the following link: - http://www.itv.com/news/2018-04-30/diane-abbott-clasheswith-tv-host-piers-morgan-over-immigration/ - Accessed $25^{\text {th }}$ July 2018

${ }^{27}$ See the following link for a brief introduction to the controversy surrounding the deportation of Black Caribbean migrants. http://www.theweek.co.uk/92944/who-are-the-windrush-generation-and-why-are-they-facing-deportation ${ }^{28}$ See Ceri Peach 'Black-Caribbeans: Class, gender and geography'. Ceri Peach (ed.) Ethnicity in the 1991 Census Vol.2 The Ethnic Minority Populations of Great Britain (London: HMSO, 1996, pp.27. See also Kehinde Andrews Resisting Racism: Race, inequality, and the Black supplementary school movement (Stoke-On-Trent: Trentham press, 2013) 
${ }^{29}$ See Bob Carter, Clive Harris and Shirley Joshi 'The 1951-1955 Conservative Government and the racialization of Black Immigration'. Kwesi Owusu (ed.) Black British Culture and Society: A Text Reader (London: Routledge, 2000), pp.21-36. See also Anthony Reddie, with Wale Hudson-Roberts and Gale Richards (eds.) Journeying to Justice:

Contributions to the Baptist Tradition Across the Black Atlantic (Milton Keynes: Paternoster Press, 2017).

${ }^{30}$ Anthony B. Pinn Terror and Triumph: The Nature of Black Religion (Minneapolis: Fortress press, 2002), pp.12-77

${ }^{31}$ Kelly Brown Douglas explores the theological dualism within platonized Christianity in her book What's Faith Got to Do With it?, pp.109-149

${ }^{32}$ Ligali, The African campaigning group based in the UK are claiming that racial violence directed at people of African descent is on the increase. In a report from the $12^{\text {th }}$ September, 2007, they claim that "A mob of violent racists who have been responsible for a number of attacks on African people are being sought by police in Tilbury, Essex. Essex Police have increased their presence in the Tilbury area, particularly around the railway station and business areas, following a number of verbal and physical assaults targeted at the local African community. Three attacks have been reported this month alone although the spate of attacks has been occurring at a rate of one every week since July 2007." Taken from 'Crime and Justice News', - from http://www.ligali.org/index.php - Accessed 27th July 2018

${ }^{33}$ The importance of Black Christianity to the multicultural nature and expression of the faith in historic churches has been expressed in a number of reports and publications. See Faithful Cities-A Call For Celebration, Vision and Justice (Peterborough and London: The Methodist Publishing House and Church House Publishing, 2006), Anthony G. Reddie, with Hudson Roberts and Gale Richards (eds.) Journeying to Justice: Black Contributions to the Baptist Tradition Across the Black Atlantic (Milton Keyes: Paternoster press, 2017), https://www.urc.org.uk/about-us/globaland-intercultural/197-global-and-intercultural-ministries.html - Accessed 4th July 2018, Tessa D. Henry-Robinson 'Qualitative Account of a Relationship Story Between the URC and BME Women'. Black Theology: An International Journal, Vol.12, No.1, 2014, pp.58-79. See also David Isiorho 'A Tale of Two Cities: Implicit Assumptions and Mission Strategies in Black and White Majority Churches'. Black Theology: An International Journal, Vol.10, No.2, 2012, pp.195-211

For helpful texts outlining the growth in Black Pentecostalism in the UK see Israel Olofinjana, Joel Edwards and Ram Gidoomal Turning the Tables on Mission: Stories of Christians from the Global South in the UK (London: Instant Apostle, 2013), Israel Olofinjana African Voices: Towards African British Theologies (Carlisle: Global Christian Publications, 2017). See also Joe Aldred and Keno Ogbo (eds.) The Black Church in the $21^{\text {st }}$ Century (London: DLT, 2010). See also David Isiorho 'A Tale of Two Cities: Implicit Assumptions and Mission Strategies in Black and White Majority Churches'. Black Theology: An International Journal, Vol.10, No.2, 2012, pp.195-211.

${ }^{34}$ See the following link for a news story in which the Archbishop of Canterbury is seen to buy into the toxic narrative of immigration concern in the UK prior to the Brexit vote. https://uk.reuters.com/article/uk-britain-eu-church/britishfears-over-immigration-should-be-addressed-archbishop-of-canterbury-idUKKCN0WD0SC - Accessed 4th July 2018

${ }^{35}$ It is important that I make the point that not all White Christians are guilty of this behaviour. Examples of alternative practices can be found in See Kenneth Leech, Through Our Long Exile (London: Darton, Longman and Todd, 2001); Kenneth Leech, Doing Theology in Altab Park (London: Darton, Longman and Todd, 2005), Kenneth Leech Race: Changing Society and the churches (London: SPCK, 2005), Kenneth Leech Struggle in Babylon: Racism in the Cities and Churches of Britain (London: Sheldon Press, 1988). See also David Haslam Race for the Millennium: The Challenge to Church and Society (London: Churches Commission for Racial Justice - CCRJ: 1996), John L. Wilkinson Church in Black and White (Edinburgh: Saint Andrews Press, 1990) and Timothy J. Gorringe Furthering Humanity: A Theology of Culture (Farnham: Ashgate, 2004)

${ }^{36}$ See Michael N. Jagessar 'A Brief Con-version: A Caribbean and Black-British Postcolonial Scrutiny of Christian Conversion'. Black Theology: An International Journal (Vol.7, No.3, 2009), pp.300-324

${ }^{37}$ Anthony G. Reddie Faith, Stories and The experience of Black Elders, pp.11-26

${ }^{38}$ Perhaps the best work that addresses issues of Whiteness and privilege in Christian theological terms is See Alison Webster You Are Mine: Reflections on Who We Are (London: SPCK, 2009).

${ }^{39}$ I have addressed this issue in my most recent self-authored book. See Anthony G. Reddie Is God Colour Blind?: Insights from Black Theology for Christian Ministry (London: SPCK, 2009), pp.37-52 